Historic, archived document

Do not assume content reflects current scientific knowledge, policies, or practices. 



\section{United States \\ Department of Agriculture}

Forest

Service

North Central

Forest Experiment

Station

Resource

Bulletin NC-133

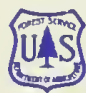

Residential Fuelwood Production and Sources From Roundwood in Minnesota, 1988

Ronald L. Hackett, Richard A. Dahlman, and W. Brad Smith

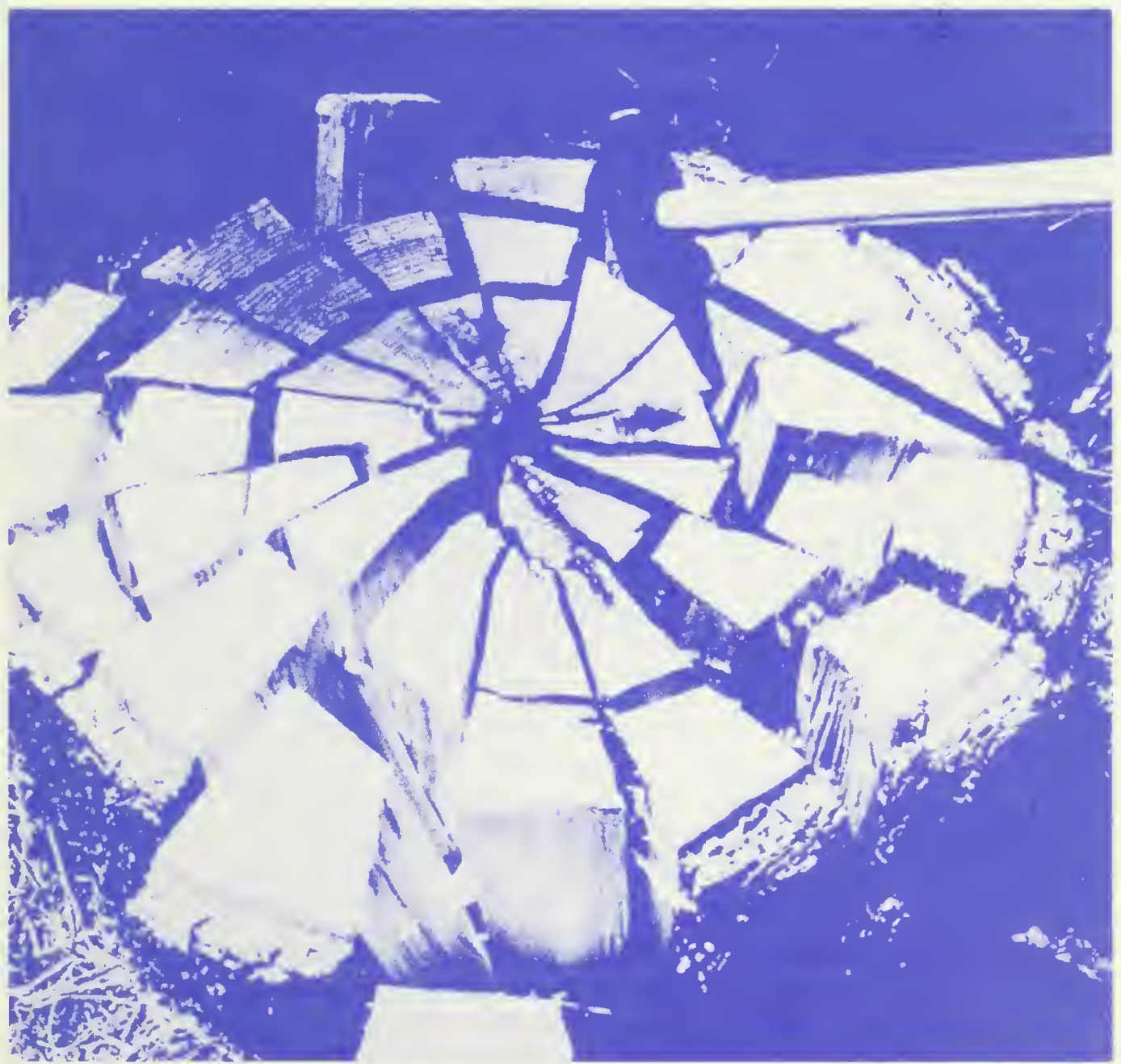


North Central Forest Experiment Station Forest Service-U.S. Department of Agriculture 1992 Folwell Avenue

St. Paul, Minnesota 55108 Manuscript approved for publication August 8, 1991 1991 


\section{FOREWORD}

This bulletin contains the results of a study of 1988 residential fuelwood production and sources in Minnesota. Such detailed information is necessary for intelligent planning and decisionmaking in wood procurement, forest resource management, and forest industry development. Likewise, researchers need current fuelwood production information for planning projects. This report does not include information about harvesting for industrial fuelwood. Such information is included in reports covering wood use by primary processing plants.

Special thanks are given to the Minnesota households and commercial fuelwood producers who supplied information for this study. Their cooperation is greatly appreciated.

We acknowledge with special thanks the Minnesota DNR and its contractors for their diligence in phoning and obtaining answers from these households and commercial fuelwood producers. 


\section{CONTENTS}

Highlights .............................................................................. 1

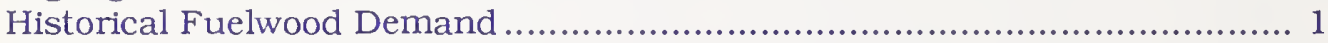

Need for a Production Study ........................................................ 2

Analysis of Production ................................................................. 2

Summary and Conclusions ........................................................... 5

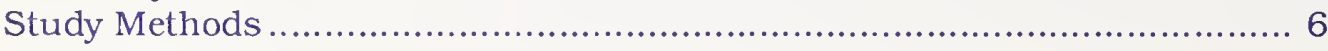

Households .......................................................................... 6

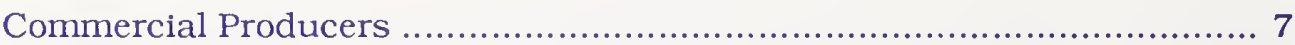

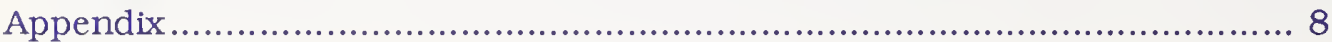

Sampling Error ...................................................................... 8

Study Limitations .............................................................. 8

Definition of Terms ................................................................ 8

Common and Scientific Names of Tree Species Mentioned .................... 9

Table Titles ................................................................................. 10 


\title{
Residential Fuelwood Production and Sources From Roundwood in Minnesota, 1988
}

\author{
Ronald L. Hackett, Richard A. Dahlman, and W. Brad Smith
}

\section{HIGHLIGHTS}

NOTE: This report contains only information about fuelwood cut by households and commercial loggers for residential use. Information about fuelwood cut for industrial use and fuelwood originating from mill residues is not included. All volumes presented here are in standard cords (128 cubic feet consisting of 79 cubic feet of wood and 49 cubic feet of bark and air space).

- Total fuel production from roundwood in 1988 was 1.1 million cords.

- More than 84 percent of the fuelwood was cut by households; the remainder was cut by commercial producers.

Ronald L. Hackett, Mensurationist, received a B.S. in forest resources from the University of Minnesota. He joined the Forest Service in December 1974 and has been working with North Central's Forest Inventory and Analysis Unit since.

Richard A. Dahlman, Marketing and Utilization Specialist, Minnesota Department of Natural Resources, Division of Forestry, received a B.S. in forest resources from the University of Minnesota and is working on an M.S. in forest ecology. He joined the Minnesota Department of Natural Resources in 1979 after working in private industry.

w. Brad Smith, Principal Mensurationist, recelved a B.S. degree in forestry and an M.S. degree in forest management from Purdue University. He joined the Forest Service in May 1977 and has been working with North Central's Forest Inventory and Analysis Unit since.
- Elm and oak comprised 56 percent of the fuelwood cut.

- Private land supplied 81 percent of the fuelwood cut.

- Rural woodlands furnished 78 percent of the fuelwood harvested.

- Of the remaining 22 percent of fuelwood cut from other land classes, 10 percent came from cities and villages; 6 percent came from fencerows, windbreaks, and rural yards; and 6 percent came from pasture and cropland.

- Growing stock on timberland was a minor source of fuelwood. An estimated 247 thousand cords (22 percent) came from growing stock on timberland.

- Dead trees on timberland provided 41 percent of the fuelwood. Nongrowing stock on timberland yielded $21 / 2$ times more volume for fuelwood than did growing stock on timberland.

\section{HISTORICAI FUELWOOD DEMAND}

Until the late 1800's wood was the primary source of energy in the United States, but by 1900 it provided only about 25 percent of this country's energy. Between 1949 and 1974. fuelwood use declined steadily for utilities, residences, and commercial businesses, although industrial fuelwood use increased steadily during that period. Wood supplied only 2 percent or 0.40 quads (0.40 quadrillion BTU's) of U.S. energy in 1972, the year before the Arab embargo sent oil prices spiraling upward. Between 1974 and 1981, spurred by higher prices for fossil fuels such as coal, oil, and natural gas, Americans increased their overall 
use of wood fuels by 45 percent, according to the U.S. Department of Energy (DOE). In 1986 wood furnished about 0.78 quads of energy, approximately 1.5 percent of the Nation's total energy consumption. Researchers at the Forest Products Laboratory of the USDA Forest Service estimate that American households burned 39 million cords of fuelwood during the 1985-1986 heating season, an amount equal to 15 percent of the Nation's total timber harvest. ${ }^{1}$ Demand for residential fuelwood is expected to exceed 50 million cords annually by the year 2010 .

\section{NEED FOR A PRODUCTION STUDY}

A study of Minnesota fuelwood production from roundwood in 1988 was necessary to provide estimates of fuelwood production for the fifth Minnesota forest inventory and to determine the impact of fuelwood production on the forest resource. Forest managers and users are asking the following kinds of questions about the magnitude of the fuelwood harvest and the sources of the wood: How much fuelwood is harvested from forest land (timberland)? Urban areas? Fencerows and windbreaks? Pastures and cropland? How much fuelwood comes from public land? Does most of the fuelwood come from growing stock? Are dead trees an important source of fuelwood? Are commercial fuelwood producers a major source? What are the principal species cut? Where are the principal fuelwood-producing areas in Minnesota? Are saw log markets threatened by fuelwood producers?

To answer these and related questions in Minnesota, a cooperative study of fuelwood production from roundwood was completed in 1988 by the North Central Forest Experiment Station and the Minnesota Department of Natural Resources.

${ }^{1}$ High, Colin; Skog, Kenneth E. 1989. Current and projected wood energy consumption in the United States. In: Proceedings of IGT conference on energy from biomass and wastes 13. Madison, WI: U.S. Department of Agriculture, Forest Service, Forest Products Laboratory. (Draft)

\section{ANALYSIS OF PRODUCTION}

Geographic source.-The Central Hardwood Survey Unit supplied 44 percent of the 1.1 million cords of fuelwood cut from roundwood in 1988. The Northern Pine Survey Unit supplied 23 percent, the Aspen-Birch Unit supplied 17 percent, and the Prairie Unit supplied 16 percent. St. Louis County was the only county to produce more than 100,000 cords of fuelwood (fig. 1).

Type of producer.-Fuelwood producers are divided into two segments-households and commercial. Households cut 84 percent of the 1988 fuelwood produced. Harvesting by commercial producers was proportionally greatest in the Northern Pine Survey Unit:

\section{Unit}

Production

Households Loggers Total
(Thousand cords)

\begin{tabular}{lrrr} 
Aspen-Birch & 141 & 52 & 193 \\
Northern Pine & 160 & 100 & 260 \\
Central Hardwood & 464 & 22 & 486 \\
Prairie & 180 & 1 & 181 \\
\cline { 2 - 4 }$\quad$ Total & 945 & 175 & 1,120
\end{tabular}

Species.-Elm and oak were the principal fuelwood species, accounting for 56 percent of the total harvested. Elm had the highest volume cut because of the many trees killed by Dutch elm disease. Leading species cut were:

$\begin{array}{lcr}\text { Species } & \begin{array}{c}\text { Volume } \\ \text { (Thousand cords) }\end{array} & \text { Percen } \\ \text { Elm } & 322 & 29 \\ \text { Oak } & 306 & 27 \\ \text { Birch } & 226 & 20 \\ \text { Maple } & 92 & 8 \\ \text { Aspen } & 86 & 8\end{array}$

No other species supplied more than 85 thousand cords. Softwoods supplied less than 4 percent of the total. 


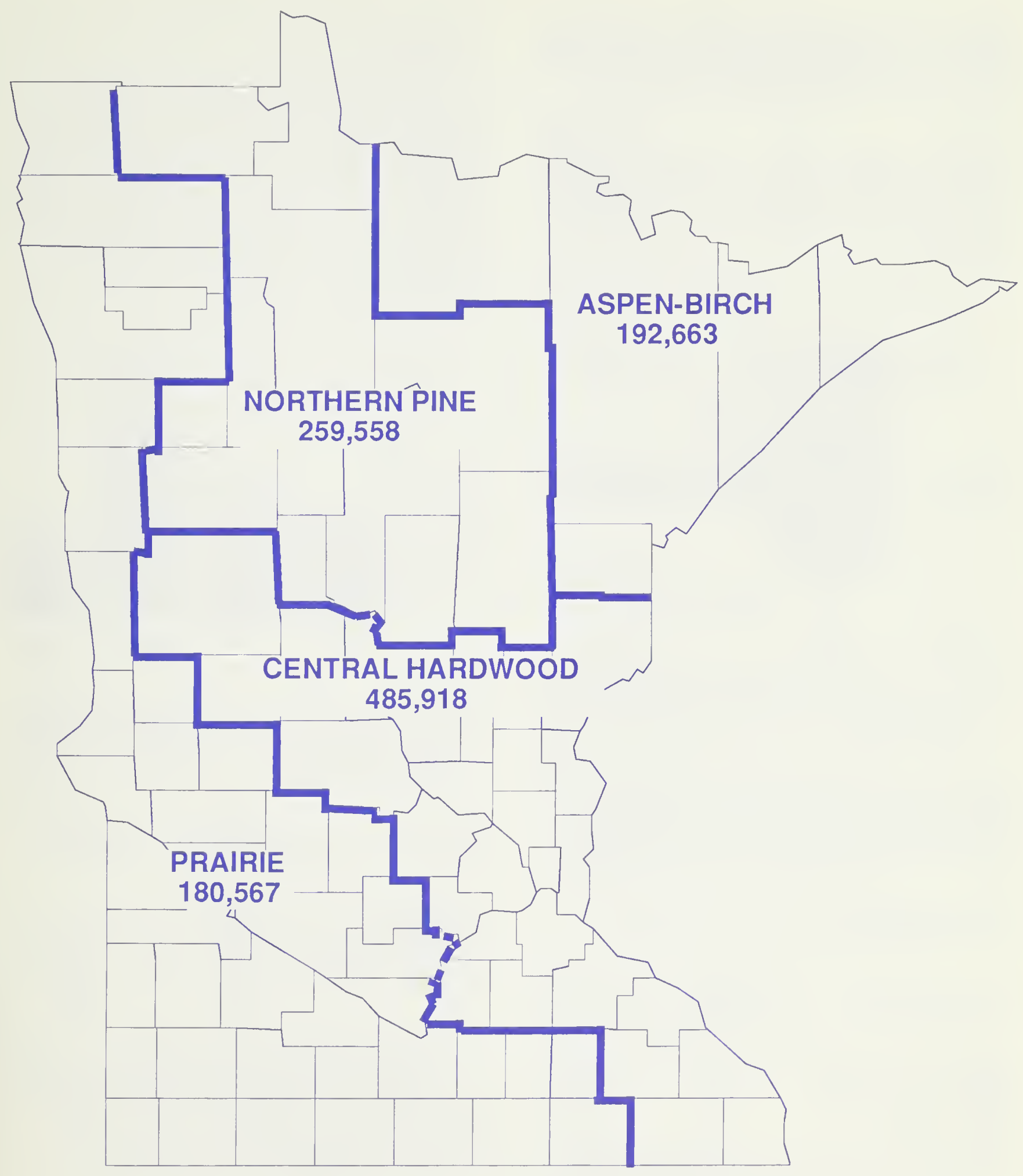

Figure 1.-Minnesota fuelwood production from roundwood by Forest Survey Unit, 1988, in standard cords. 
The predominant fuelwood species cut in each Survey Unit were birch and aspen (Aspen-Birch Unit), oak and birch (Northern Pine Unit), and elm and oak (Central Hardwood and Prairie Units).

Private vs. public land.-Private land provided 82 percent of the fuelwood cut. Public land furnished more than 30 percent of fuelwood cut in each of the Aspen-Birch and Northern Pine Units (fig. 2).

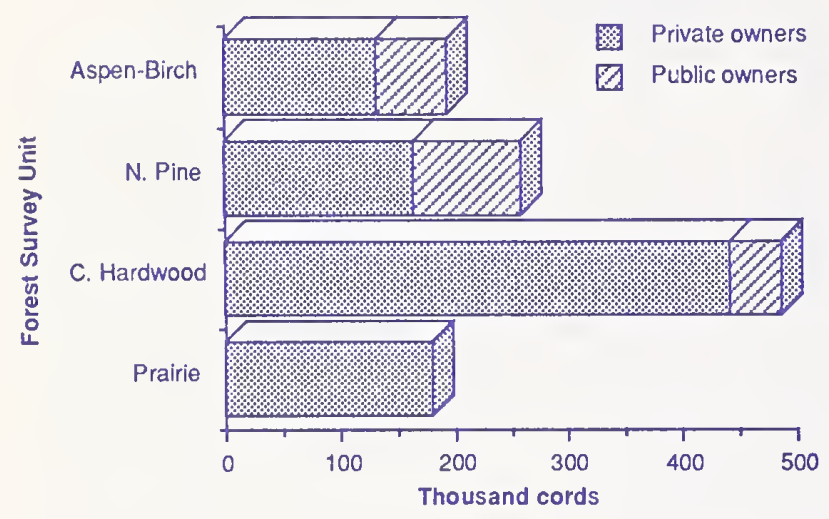

Figure 2.-Residential fuelwood production from roundwood by Forest Survey Unit and major owner class.

Forest industry land (owned by firms with primary wood-using mills) supplied only 14 thousand cords of fuelwood. Forest industry owns a nominal amount of Minnesota land.

State land was the chief source of fuelwood from the public sector:

Public land class

Fuelwood volume (Thousand cords) (Percent)

State

\begin{tabular}{rr}
105 & 52 \\
62 & 31 \\
23 & 11 \\
12 & 6 \\
\hline 202 & 100
\end{tabular}

Birch and oak were the primary species cut on State land.

Rural woodlands ${ }^{2}$ supplied 78 percent of the residential fuelwood in the State (fig. 3). The remainder came from diverse sources such as cities and villages; windbreaks, fencerows, and yards of homes in rural areas; and pasture and cropland. Rural woodland supplied more than 68 percent of the fuelwood in the more heavily forested Aspen-Birch, Northern Pine, and Central Hardwood Units and 10 percent of the fuelwood in the Prairie Unit:

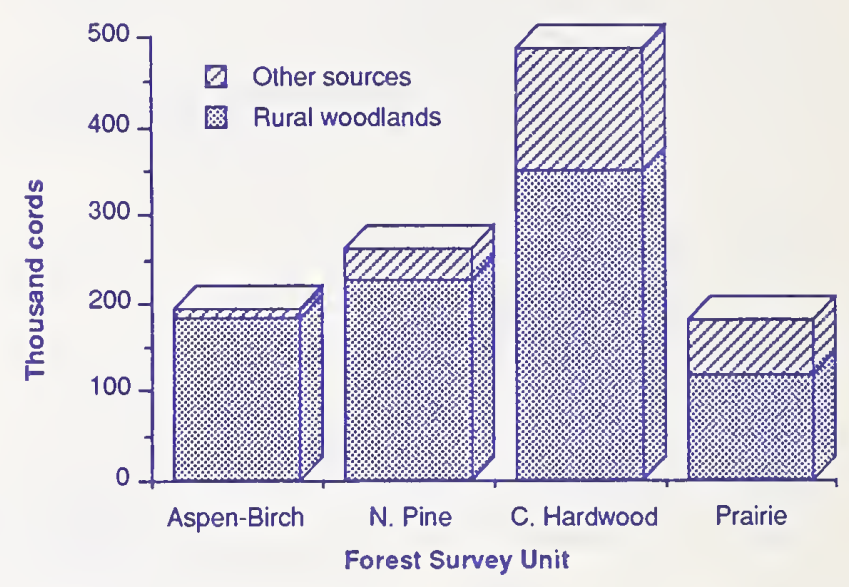

Figure 3.-Residential fuelwood production from roundwood by Forest Survey Unit and major source of material.

Unit

$\begin{array}{cc}\begin{array}{c}\text { Rural } \\ \text { woodlands }\end{array} & \begin{array}{l}\text { Other } \\ \text { land }\end{array}\end{array}$
(Thousand cords)

Aspen-Birch
Northern Pine
Central Hardwood
Prairie
All

\begin{tabular}{rr}
182 & 11 \\
223 & 36 \\
350 & 136 \\
117 & 63 \\
\hline 872 & 246
\end{tabular}

"Rural woodlands" as used in the survey questionnaire was the area outside city and village limits, fencerows, windbreaks, yards of homes, pasture and cropland from where fuelwood was harvested. It was assumed to be timberland. 
Of the 22 percent of fuelwood harvested from other sources (nontimberland and nonforest land areas), 10 percent came from cities and villages; 6 percent came from fencerows, windbreaks, and rural yards; and 6 percent came from pasture and cropland. Elm and oak were the principal species cut on these lands. The heavily urbanized Central Hardwood Unit produced 55 percent (136 thousand cords) of the residential fuelwood from other sources (cities, villages, rural yards, windbreaks, etc.).

\section{Growing stock vs. nongrowing stock.-} Growing stock (see Definition of Terms in Appendix) on timberland was not a major source of fuelwood. Of the 1.1 million cords of fuelwood cut from roundwood, only an estimated 247 thousand cords ( 22 percent) came from growing stock on timberland. Producers cut another 625 thousand cords (56 percent) from nongrowing stock on timberland:

\section{Source}

\section{Volume of fuelwood (Thousand cords)}

\section{Growing stock on timberland}

Tops and limbs of growing-stock trees

Cull trees and sections

Dead trees on timberland

Saplings

All trees on nonforest and nontimberland Total

\begin{tabular}{rr}
247 & 22 \\
129 & 11 \\
& \\
41 & 4 \\
454 & 41 \\
1 & $\left({ }^{3}\right)$ \\
& \\
246 & 22 \\
\hline 1,118 & 100
\end{tabular}

Nonforest sources (such as cities, villages, pasture, cropland, fencerows, and windbreaks) supplied the other 246 thousand cords ( 22 percent).

None of the units harvested large quantities of fuelwood from growing stock on timberland for fuelwood. The highest proportion cut from growing stock was in the Aspen-Birch Unit:

\footnotetext{
${ }^{3}$ Less than 0.5 percent.
}

Unit

Fuelwood cut from growing stock

Percent of (Thousand cords) Unit total

Aspen-Birch 84 43

Northern Pine 91 35

Central Hardwood 57 12

Prairie

State total $\frac{15}{247}$

Harvesting of dead trees on timberland for fuel was proportionally higher in the Central Hardwood Unit because of disease, weather, construction, and logging; the major urban areas in this Unit. Elm and oak were the primary species of dead trees harvested.

Unit

Aspen-Birch

Northern Pine

Central Hardwood

Prairie

State total

\section{Fuelwood from dead trees} on timberland (Thousand cords)
Percent

\begin{tabular}{rr}
42 & 10 \\
68 & 15 \\
251 & 55 \\
93 & 20 \\
\hline 454 & 100
\end{tabular}

For reporting purposes, the volumes of several miscellaneous species were combined into aggregate groups of "other softwoods," "other hardwoods," and "noncommercial" species. These data were considered too weak to report at the county level. Table 3 shows the distribution of these species as reported by households on a Survey Unit basis.

\section{SUMMMARY AND CONCLUSIONS}

Total output of fuelwood during 1988 in Minnesota from roundwood was 1.1 million cords. This volume of fuelwood contained sufficient heat value to replace approximately 110 million gallons of No. 2 fuel oil ${ }^{4}$. More than 96 percent of the fuelwood produced was from hardwoods.

\footnotetext{
${ }^{4}$ In comparing heat value between fuels, another factor to consider is the energy required to produce and deliver the fuels to the consumer.
} 
The Central Hardwood Unit, contains 23 percent of all Minnesota land area, and about 18 percent of the forest land, but it produced 43 percent of the fuelwood volume. The denser population in the Central Hardwood Unit compared to the rest of the State was a major reason for the greater intensity of fuelwood harvesting there.

Households outproduced commercial cutters by a ratio of 7 to 1 statewide. Private nonforest land was the chief source of fuelwood. Seventyeight percent of the production was from rural woodlands, but nearly 52 percent of fuelwood cut from rural woodlands came from dead trees.

Growing stock on timberland was a minor source of fuelwood, accounting for only 22 percent of the production. Nongrowing stock on timberland yielded $21 / 2$ times the volume of fuelwood that growing stock did. Dead trees on timberland accounted for 41 percent of fuelwood produced.

Commercial producers cut a nominal amount of fuelwood in 1988. However, they cut a much greater proportion from growing stock on timberland (2 $1 / 2$ times more) than households cut. If commercial producers become more important suppliers of fuelwood, the percentage of growing stock in the mix of fuelwood can be expected to rise.

Some forest managers and wood procurement managers in Minnesota may fear that large quantities of fuelwood are being cut from growing stock that previously would have been used for saw logs and other forest products. Our study results should relieve many of their concerns. Much of the fuelwood is from dead trees unlikely to be suitable for other products and from trees on nonforest land. These trees are not generally a forest industry supply source.

During the next 5 to 10 years, growing stock is likely to remain a minor source of Minnesota fuelwood. Large quantities of dead trees, tops and limbs, and trees on nonforest land will be available each year for fuelwood use. Followup fuelwood studies at 5-year intervals would be useful in determining trends in harvesting growing stock for fuel. Changes in the commercial to household fuelwood production ratio will be significant in determining the proportion of fuelwood cut from growing stock on timberland.

Use of dead and cull trees on timberland for fuel provides a certain level of timber stand improvement for increased productivity. As demand for fuelwood has increased, more of these trees have been removed for a profit as fuel. Consequently, less money has been required for a given level of timber stand improvement than if fuelwood demand had remained at low levels.

\section{STUDY METHODS}

Data for this publication came from sampling Minnesota households and canvassing all known commercial fuelwood producers with formal questionnaires approved by the Federal Office of Management and Budget.

\section{Households}

The sampled universe was all households in Minnesota with listed telephones. Minnesota was divided into two districts: (1) the Twin Cities District, containing 788,200 households and (2) the Outside Twin Cities District, containing 797,700 households. The Twin Cities District contains Anoka, Dakota, Hennepin, Ramsey, and Washington Counties.

A total sample size of 1,481 households was selected based on funding avallable and a desired standard error of less than \pm 20 percent statewide at one standard deviation. The sample size ranged from 4 households in Traverse County to 255 households in Hennepin County. A total of 290 sample households indicated that they cut fuelwood in 1988.

Households were selected for the sample by the Minnesota DNR using systematic random sampling techniques. In each district, households were selected from current phone books using the following procedures: 
1. Collect all current phone directories within the county.

2. Eliminate all duplicate books and numbers.

3. Estimate the total number of residential numbers in each book. Eliminate all nonhousehold numbers (business, institutional, etc.) in each book. Record the number of pages per book.

4. Determine the number of calls to be made from each book and the interval per call by the following equations:

a. Total residential numbers in all books divided by sample size equals interval per call.

b. Number of residential phones per book divided by interval per call equals number of calls needed from this book.

c. Number of pages per book divided by number of calls per book equals interval per call for this book.

5. The nth name in the nth column, depending on the interval per call, was selected for the call. Minnesota DNR personnel interviewed the sample households by phone using a formal questionnaire prepared by the North Central Forest Experiment Station. The survey was conducted over a 5-week period beginning May 1989. Calls were made primarily during the evening hours.

Initial editing of the questionnaires was completed by Minnesota DNR personnel. The North Central Station did the final editing and compiled the data. Some respondents did not know the species cut for fuel, except in general terms such as mixed hardwoods. To facilitate reporting for each county, we prorated mixed hardwoods proportionately to each of the hardwood species specifically identified as being harvested in that county.
Sampling rates were about four times higher in the Outside Twin Cities District than in the heavily populated Twin Cities District. Expansion factors were determined for households by dividing the number of households in a district by the number of sample households in that district. These expansion factors were used to estimate the total fuelwood production by households in each county. Table 8 in the appendix shows the sample sizes and expanders by districts.

\section{Commercial Producers}

A list of commercial fuelwood producers was compiled for each county by the Minnesota DNR. Sources of the compilation were the yellow pages of Minnesota telephone directories and Minnesota newspaper ads for fuelwood available for sale. Newspaper ads were scanned for several months and 1,000 commercial producers were found. A total of 101 loggers from this sample indicated that they produced fuelwood in 1988.

Using a formal questionnaire similar to that used for households, Minnesota DNR personnel canvassed all the commercial producers by phone during the summer of 1988. Possible duplicate sampling of commercial producers was minimized by questioning all sample households producing more than 20 cords of fuelwood to determine if they were commercial producers.

Logging utilization factors for fuelwood were used in estimating the quantity of growing stock cut for fuelwood on timberland. The Station developed these factors in Michigan during 1964-1965 by measuring trees cut for fuelwood on active harvesting operations. Sixty-seven percent of the fuelwood cut from live trees on timberland was estimated to be from the growing-stock portion of the trees. An estimated 27 percent of the fuelwood cut or collected from logging residue on timberland was also from the growing-stock portion of the trees. 


\section{APPENDLX}

\section{SAMPLING ERROR}

All the reported figures are estimates based on sampling procedures that are designed to give accurate estimates of fuelwood production. A measure of reliability of these figures is given by sampling errors. This sampling error means that the chances are two out of three that the results for the sample differ by no more than the amount indicated from the results that would have been obtained if a complete census of all households and commercial producers had been made. The total sampling error for fuelwood production in Minnesota was \pm 13.6 percent on a volume of 1.1 million cords.

Sampling errors by sample unit were as follows:

\section{Sample Unit}

\section{Volume \\ (Thousand cords)}

Error

(Percent)

Aspen-Birch

Northern Pine

Central Hardwood ${ }^{5}$

Prairie

All Units

$\begin{array}{r}140.2 \\ 149.3 \\ 485.4 \\ 170.0 \\ \hline 1,118.7\end{array}$

35.6

16.7

20.0

17.3

13.6
To obtain a sampling error of \pm 10 percent, it would have been necessary to call a total of 3,364 households, instead of the 1,481 households in our sample.

\section{STUDY LIMITATIONS}

Two components of total fuelwood production are not included in this report. First, fuelwood produced from wood residue generated at primary wood-using mills (such as sawmills and cooperage mills) is not included. However, a cooperative Minnesota primary wood-using mill study by the Minnesota DNR and the North Central Forest Experiment Station will provide an estimate of fuelwood produced from primary mill residue. Information on this source of fuelwood will be published in another paper.

\footnotetext{
${ }^{5}$ Includes the Twin Cities District.
}

Second, fuelwood produced from wood residue generated at secondary wood-using mills (such as millwork plants; furniture plants, and office and store equipment manufacturers) was not estimated. Secondary wood-using mill residue is a minor source of fuelwood that has no direct impact and only a nominal indirect influence on the forest resource used for fuel.

Households without listed telephones were not sampled. Study results may be slightly biased if the fuelwood harvest per household without listed phones is significantly different in quantity or sources from the fuelwood harvest per household with listed phones. Harvesting characteristics by these two groups were assumed to be similar, and expansion factors for estimating total fuelwood production took into account all households in Minnesota.

Respondents were asked how much fuelwood they cut during the previous 12 months. Each commercial producer was asked a similar question. Because the study was conducted during several months in 1988, the actual fuelwood harvest was for varying 12 -month periods in 1987 and 1988, depending on when the respondent was called. For this paper, production has been dated as 1988 for ease of discussion. It is assumed that the exact date does not significantly affect the analysis or findings.

Commercial producers who do not advertise in the yellow pages or in newspapers were not included in the study. However, because the producers in the study cut small quantities of fuelwood, we believe the quantity excluded is insignificant.

\section{DEFINITION OF TERMS}

Commercial producers.-Commercial fuelwood operators. Those who harvest fuelwood to sell to dealers or consumers. Includes loggers who harvest fuelwood along with saw logs and other products. 
Forest industry land.-Land owned by companies or individuals operating primary wood-using mills.

Fuelwood production.-Fuelwood harvest. The fuelwood portion of roundwood production. The fuelwood volume of roundwood products.

Growing-stock (volume).-Net volume in cubic feet of growing-stock trees 5.0 inches d.b.h. and over, from a 1 -foot stump to a minimum 4.0-inch top diameter outside bark of the central stem.

Logging residue.-The unused portions of trees cut or killed by logging.

Logging waste.-See Logging residue.

National Forest land.-Federal land that has been legally designated as National Forest or purchase units, and other land under the administration of the USDA Forest Service.

Nonforest land.-Land that has never supported forests, and land formerly forested where use for timber management is precluded by development for other uses. Includes areas used for crops, improved pasture, residential areas, city parks, improved roads of any width and adjoining clearings, powerline clearings of any width. and 1 - to 40-acre areas of water classified by the Bureau of the Census as land.

Nontimberland.-See Nonforest land.

Primary wood-using mills.-Mills receiving roundwood or chips from roundwood for processing into products.

\section{Primary wood-using mill residue.-Wood}

materials (coarse and fine) and bark generated at manufacturing plants from roundwood processed into principal products. These residues include wood products (byproducts) obtained incidental to production of principal products and wood materials not utilized for some product.
Roundwood.-Logs and bolts from harvested trees including chips produced directly from harvested trees.

Standard cord.-A pile of logs $4 \times 4 \times 8$ feet ( 128 cubic feet including air space and bark). A cord of fuelwood contains 79 cubic feet of wood and 49 cubic feet of bark and air space.

State land.-Land owned by States or land leased to these governmental units for 50 years or more.

Timberland.-Forest land producing or capable of producing crops of industrial wood and not withdrawn from timber utilization. Areas qualifying as timberland have the capability of producing in excess of 20 cubic feet per acre per year of annual growth under management. Currently inaccessible and inoperable areas are included, except when the areas involved are small and unlikely to become suitable for production of industrial wood in the foreseeable future. In this paper, "woodland areas outside city or village limits (rural woodland)" were assumed to be timberland.

Woodland.-See Timberland.

\section{COMMON AND SCIENTIFIC NAMES OF TREE SPECIES MENTIONED}

\section{SOFTWOODS}

Cedar Thuja occidentalis

Balsam fir Abies balsamea

Spruce

White spruce ............................Picea glauca

Black spruce ...........................Picea mariana

White pine .................................Pinus strobus

Red pine ..................................Pinus resinosa

Jack pine .............................. Pinus banksiana

Tamarack ................................... Larix laricina

HARDWOODS

Ash

Black ash ............................ Fraxinus nigra

White ash ....................... Fraxinus americana

Green ash .................. Fraxinus pennsylvanica

Aspen

Bigtooth aspen ............. Populus grandidentata

Quaking aspen .................Populus tremuloides 
Balsam poplar Populus balsamifera

American basswood . Tilia americana

Birch

Paper birch Betula papyrifera

Yellow birch Betula alleghaniensis

Elm

American elm Ulmus americana

Rock elm Ulmus thomasii

Slippery elm . Ulmus rubra

Hickory

Shagbark hickory Carya ovata

Bitternut hickory Carya cordiformis

Hard maple

Sugar maple Acer saccharum

Black maple Acer nigrum

Soft maple

Red maple Acer rubrum

Silver maple saccharinum

Red oak

Northern red oak

Black oak Quercus rubra

Northern pin oak

White oak

White oak Quercus alba

Bur oak us macrocarpa

Swamp white oak Quercus bicolor

Black walnut Juglans nigra

Butternut Juglans cinerea

Black cherry Prunus serotina

Other hardwoods

Boxelder Acer negundo

River birch Betula nigra

Hackberry Celtis occidentalis

Eastern cottonwood Populus deltoides

Black willow Salix nigra

Kentucky coffeetree

Noncommercial

Ironwood

Apple
TABLE TITLES

Table 1.-Fuelwood production from roundwood by species group and source of material, Minnesota, 1988

Table 2.-Fuelwood production from roundwood by species group and owner class, Minnesota, 1988

Table 3.-Fuelwood production distribution for "other softwoods," "other hardwoods," and "noncommercial" species groups by individual species and Forest Survey Unit, Minnesota, 1988

Table 4.-Fuelwood production from roundwood by Forest Survey Unit and source of material, Minnesota, 1988

Table 5.-Fuelwood production from roundwood by Forest Survey Unit and owner class, Minnesota, 1988

Table 6.-Distributed fuelwood production from roundwood by Forest Survey Unit and source of material, Minnesota, 1988

Table 7. Fuelwood production from roundwood by Forest Survey Unit and species group, Minnesota, 1988

Table 8.-Sampling universe and allocation for fuelwood study by sample district, Minnesota, 1988 
Table 1. -Fuelwood production from roundwood by species group and source of material, Minnesota, 1988

\begin{tabular}{|c|c|c|c|c|c|c|c|}
\hline \multirow[b]{2}{*}{ Species group } & \multirow[b]{2}{*}{$\begin{array}{c}\text { All } \\
\text { sources }\end{array}$} & \multirow[b]{2}{*}{$\begin{array}{c}\text { Cities } \\
\text { and } \\
\text { villages }\end{array}$} & \multirow{2}{*}{$\begin{array}{l}\text { Windbreaks, } \\
\text { fencerows, } \\
\text { and rural } \\
\text { yards }\end{array}$} & \multicolumn{4}{|c|}{ Rural woodlands } \\
\hline & & & & $\begin{array}{l}\text { Pasture } \\
\text { and } \\
\text { cropland }\end{array}$ & $\begin{array}{c}\text { Standing } \\
\text { live } \\
\text { trees }\end{array}$ & $\begin{array}{c}\text { Logging } \\
\text { waste }\end{array}$ & $\begin{array}{l}\text { Dead } \\
\text { trees }\end{array}$ \\
\hline \multicolumn{8}{|c|}{ In standard cords } \\
\hline Pine & 34,958 & 3,097 & 843 & 1,515 & 10,339 & 1,174 & 17,990 \\
\hline Other softwoods & 3,886 & - & - & - & 1,066 & - & 2,820 \\
\hline Total softwoods & 38,844 & 3,097 & 843 & 1,515 & 11,405 & 1,174 & 20,810 \\
\hline Oak & 306,122 & 28,238 & 14,080 & 30,468 & 86,697 & 15,700 & 130,939 \\
\hline Basswood & 3,899 & 29 & 13 & 791 & 998 & 265 & 1,803 \\
\hline Birch & 226,426 & 11,950 & 5,474 & 2,478 & 153,504 & 13,745 & 39,275 \\
\hline Maple & 91,631 & 7,344 & 3,950 & 5,699 & 38,743 & 3,902 & 31,993 \\
\hline Elm & 321,822 & 57,243 & 16,380 & 18,332 & 47,744 & 6,427 & 175,696 \\
\hline Aspen & 86,025 & 1,207 & 5,751 & 9,289 & 31,616 & 5,051 & 33,111 \\
\hline Other hardwoods & 38,633 & 4,149 & 10,917 & 3,593 & 1,319 & 150 & 18,505 \\
\hline Noncommercial & 5,304 & 104 & 3,100 & 309 & 158 & - & 1,633 \\
\hline Total hardwoods & $1,079,862$ & 110,264 & 59,665 & 70,959 & 360,779 & 45,240 & 432,955 \\
\hline All species & $1,118,706$ & 113,361 & 60,508 & 72,474 & 372,184 & 46,414 & 453,765 \\
\hline
\end{tabular}

Table 2.-Fuelwood production from roundwood by species group and owner class, Minnesota, 1988

\begin{tabular}{|c|c|c|c|c|c|c|c|}
\hline Species group & $\begin{array}{c}\text { All } \\
\text { ownerships }\end{array}$ & $\begin{array}{c}\text { Federal } \\
\text { National } \\
\text { forest }\end{array}$ & Other & State & $\begin{array}{l}\text { County and } \\
\text { municipal }\end{array}$ & $\begin{array}{l}\text { Forest } \\
\text { industry }\end{array}$ & $\begin{array}{c}\text { Other } \\
\text { private }\end{array}$ \\
\hline Pine & 34,958 & 53 & 250 & 2,484 & 61 & 51 & 32,059 \\
\hline Other softwoods & 3,886 & 15 & - & 900 & 15 & - & 2,956 \\
\hline \multirow[t]{2}{*}{ Total softwoods } & 38,846 & 68 & 250 & 3,384 & 76 & 51 & 35,015 \\
\hline & \multicolumn{7}{|c|}{ In standard cords } \\
\hline Oak & 306,122 & 3,678 & 4,174 & 35,031 & 14,970 & 1,339 & 246,930 \\
\hline Basswood & 3,899 & - & - & 247 & 4 & - & 3,648 \\
\hline Birch & 226,426 & 13,395 & 4,649 & 40,801 & 26,914 & 2,292 & 138,375 \\
\hline Maple & 91,631 & 2,276 & 1,954 & 9,898 & 7,646 & 349 & 69,508 \\
\hline Elm & 321,822 & 1,483 & 378 & 5,618 & 9,278 & 9,820 & 295,245 \\
\hline Aspen & 86,025 & 1,894 & 150 & 9,881 & 1,394 & 78 & 72,628 \\
\hline Other hardwoods & 38,633 & 150 & - & 342 & 1,307 & - & 36,834 \\
\hline Noncommercial & 5,304 & - & - & - & - & - & 5,304 \\
\hline Total hardwoods & $1,079,862$ & 22,876 & 11,305 & 101,818 & 61,513 & 13,878 & 868,472 \\
\hline All species & $1,118,706$ & 22,944 & 11,555 & 105,202 & 61,589 & 13,929 & 903,487 \\
\hline
\end{tabular}


Tabie 3.-Fuelwood production distribution for "other softwoods," "other hardwoods," and "noncommerical" species groups by individual species and Forest Survey Unit, Minnesota, 1988

In standard cords

\begin{tabular}{lrrrrr}
\hline & & \multicolumn{4}{c}{ Forest Survey Unit } \\
\cline { 3 - 6 } Species group & All units & Aspen-Birch & $\begin{array}{c}\text { Northern } \\
\text { Pine }\end{array}$ & $\begin{array}{c}\text { Central } \\
\text { Hardwood }\end{array}$ & Prairie \\
\hline \multicolumn{5}{c}{ OTHER SOFTWOODS } \\
Spruce & 434 & 315 & - & 119 & - \\
Baisam fir & 2,644 & 2,408 & 236 & - & - \\
Tamarack & 788 & - & 788 & - & - \\
Unspecified softwoods & 20 & 20 & - & - & - \\
$\quad$ Total & 3,886 & 2,743 & 1,024 & 119 & - \\
\hline
\end{tabular}

OTHER HARDWOODS

\begin{tabular}{|c|c|c|c|c|c|}
\hline Hickory & 3,324 & - & - & 3,324 & - \\
\hline Wainut & 2,755 & 一 & - & - & 2,755 \\
\hline Butternut & 76 & - & - & 76 & - \\
\hline Boxelder & 12,701 & 33 & 591 & 1,584 & 10,493 \\
\hline Cottonwood & 11,009 & 一 & - & 1,093 & 9,916 \\
\hline Willow & 4,865 & - & - & - & 4,865 \\
\hline Unspecified hardwoods & 3,903 & 3 & 785 & 723 & 2,392 \\
\hline Total & 38,633 & 36 & 1,376 & 6,800 & 30,421 \\
\hline \multicolumn{6}{|c|}{ NONCOMMERCIAL } \\
\hline Apple & 724 & - & - & - & 724 \\
\hline Ironwood & 4,580 & 一 & - & 4,322 & 258 \\
\hline Total & 5,304 & - & - & 4,322 & 982 \\
\hline
\end{tabular}


Table 4.-Fuelwood production from roundwood by Forest Survey Unit and source of material, Minnesota, 1988

\begin{tabular}{|c|c|c|c|c|c|c|c|}
\hline \multirow[b]{2}{*}{ Forest Survey Unit } & \multirow[b]{2}{*}{$\begin{array}{c}\text { All } \\
\text { sources }\end{array}$} & \multirow[b]{2}{*}{$\begin{array}{c}\text { Cities } \\
\text { and } \\
\text { villages }\end{array}$} & \multirow{2}{*}{$\begin{array}{c}\text { Windbreaks } \\
\text { fencerows } \\
\text { and rural } \\
\text { yards }\end{array}$} & \multicolumn{4}{|c|}{ Rural woodlands } \\
\hline & & & & $\begin{array}{l}\text { Pasture } \\
\text { and } \\
\text { cropland }\end{array}$ & $\begin{array}{c}\text { Standing } \\
\text { live } \\
\text { trees }\end{array}$ & $\begin{array}{c}\text { Logging } \\
\text { waste }\end{array}$ & $\begin{array}{l}\text { Dead } \\
\text { trees }\end{array}$ \\
\hline \multicolumn{8}{|c|}{ In standard cords } \\
\hline Aspen-Birch & 192,663 & 1,034 & 8,687 & 922 & 127,557 & 12,116 & 42,347 \\
\hline Northern Pine & 259,558 & 552 & 8,593 & 27,088 & 135,685 & 20,020 & 67,620 \\
\hline Central Hardwood & 485,918 & 101,885 & 14,778 & 19,546 & 84,547 & 14,158 & 251,004 \\
\hline Prairie & 180,567 & 9,890 & 28,450 & 24,918 & 24,395 & 120 & 92,794 \\
\hline State total & $1,118,706$ & 113,361 & 60,508 & 72,474 & 372,184 & 46,414 & 453,765 \\
\hline
\end{tabular}

Table 5.-Fuelwood production from roundwood by Forest Survey Unit and owner class, Minnesota, 1988

\begin{tabular}{|c|c|c|c|c|c|c|c|}
\hline \multirow[b]{2}{*}{ Forest Survey Unit } & \multirow[b]{2}{*}{$\begin{array}{c}\text { All } \\
\text { ownerships }\end{array}$} & \multicolumn{2}{|c|}{ Federal } & \multirow[b]{2}{*}{ State } & \multirow[b]{2}{*}{$\begin{array}{l}\text { County and } \\
\text { municipal }\end{array}$} & \multirow[b]{2}{*}{$\begin{array}{l}\text { Forest } \\
\text { industry }\end{array}$} & \multirow[b]{2}{*}{$\begin{array}{c}\text { Other } \\
\text { private }\end{array}$} \\
\hline & & $\begin{array}{c}\text { National } \\
\text { forest }\end{array}$ & Other & & & & \\
\hline \multicolumn{8}{|c|}{ In standard cords } \\
\hline Aspen-Birch & 192,663 & 10,923 & 5,851 & 27,808 & 16,023 & 2,580 & 129,478 \\
\hline Northern Pine & 259,558 & 12,021 & 5,704 & 46,582 & 30,682 & 1,352 & 163,117 \\
\hline Central Hardwood & 485,918 & - & - & 30,372 & 14,884 & 9,997 & 430,665 \\
\hline Prairie & 180,567 & - & - & 440 & - & - & 180,127 \\
\hline State total & $1,118,706$ & 22,944 & 11,555 & 105,202 & 61,589 & 13,929 & 903,387 \\
\hline
\end{tabular}

Table 6.-Distributed fuelwood production from roundwood by Forest Survey Unit and source of material, Minnesota, 1988

\begin{tabular}{|c|c|c|c|c|c|c|c|c|}
\hline \multirow[b]{3}{*}{ Forest Survey Unit } & \multirow[b]{3}{*}{$\begin{array}{l}\text { Total all } \\
\text { sources }\end{array}$} & \multicolumn{6}{|c|}{ Timberland } & \multirow[b]{3}{*}{$\begin{array}{c}\text { Non- } \\
\text { timberland }\end{array}$} \\
\hline & & \multirow[b]{2}{*}{$\begin{array}{l}\text { Total from } \\
\text { timberland }\end{array}$} & \multicolumn{2}{|c|}{ Growing stock } & \multirow[b]{2}{*}{ Saplings } & \multirow[b]{2}{*}{$\begin{array}{l}\text { Cull } \\
\text { trees }\end{array}$} & \multirow[b]{2}{*}{$\begin{array}{l}\text { Dead } \\
\text { trees }\end{array}$} & \\
\hline & & & Boles & $\begin{array}{c}\text { Tops and } \\
\text { limbs }\end{array}$ & & & & \\
\hline \multicolumn{9}{|c|}{ In standard cords } \\
\hline Aspen-Birch & 192,663 & 182,020 & 83,632 & 42,187 & 381 & 13,472 & 42,347 & 10,643 \\
\hline Northern Pine & 259,558 & 223,325 & 90,887 & 48,795 & 441 & 15,582 & 67,620 & 36,233 \\
\hline Central Hardwood & 485,918 & 349,709 & 57,087 & 31,330 & 283 & 10,005 & 251,004 & 136,209 \\
\hline Prairie & 180,567 & 117,309 & 15,401 & 6,861 & 62 & 2,191 & 92,794 & 63,258 \\
\hline State total & $1,118,706$ & 872,363 & 247,008 & 129,173 & 1,167 & 41,250 & 453,765 & 246,343 \\
\hline
\end{tabular}


Table 7.-Fuelwood production from roundwood by Forest Survey Unit and species group, Minnesota, 1988

\begin{tabular}{|c|c|c|c|c|c|}
\hline \multirow[b]{2}{*}{ Species group } & \multicolumn{2}{|c|}{ Forest Survey Unit } & & & \multirow[b]{2}{*}{ Prairie } \\
\hline & State total & $\begin{array}{l}\text { Aspen- } \\
\text { Birch }\end{array}$ & $\begin{array}{l}\text { Northern } \\
\text { Pine }\end{array}$ & $\begin{array}{l}\text { Central } \\
\text { Hardwood }\end{array}$ & \\
\hline \multirow{4}{*}{$\begin{array}{l}\text { Pine } \\
\text { Other softwoods } \\
\text { Total softwoods }\end{array}$} & \multicolumn{4}{|c|}{ In standard cords } & \multirow[b]{2}{*}{1,142} \\
\hline & 34,958 & 6,727 & 12,206 & 14,883 & \\
\hline & 3,886 & 2,743 & 1,024 & 119 & - \\
\hline & 38,844 & 9,470 & 13,230 & 15,002 & 1,142 \\
\hline Oak & 306,122 & 13,223 & 79,014 & 174,350 & 39,535 \\
\hline Basswood & 3,899 & 0 & 1,662 & 1,678 & 559 \\
\hline Birch & 226,426 & 112,859 & 66,065 & 41,821 & 5,681 \\
\hline Maple & 91,631 & 18,270 & 20,829 & 35,931 & 16,601 \\
\hline Elm & 321,822 & 13,593 & 38,194 & 187,234 & 82,801 \\
\hline Aspen & 86,025 & 25,212 & 39,188 & 18,780 & 2,845 \\
\hline Other hardwoods & 38,633 & 36 & 1,376 & 6,800 & 30,421 \\
\hline Noncommercial & 5,304 & -- & -- & 4,322 & 982 \\
\hline Total Hardwoods & $1,079,862$ & 183,193 & 246,328 & 470,916 & 179,425 \\
\hline All species & $1,118,706$ & 192,663 & 259,558 & 485,918 & 180,567 \\
\hline
\end{tabular}

Table 8.-Sampling universe and allocation for fuelwood study by sample district, Minnesota, 1988

\begin{tabular}{lcccc}
\hline Sample Districts & $\begin{array}{c}\text { Number of } \\
\text { households }\end{array}$ & $\begin{array}{c}\text { Planned } \\
\text { sample }\end{array}$ & $\begin{array}{c}\text { Actual } \\
\text { sample }^{2}\end{array}$ & $\begin{array}{c}\text { Actual } \\
\text { sample rate }\end{array}$ \\
\hline Aspen-Birch & 102,600 & 300 & 263 & 390.1 \\
Northern Pine & 91,300 & 250 & 232 & 393.5 \\
Central Hardwood & 311,900 & 386 & 314 & 993.3 \\
Prairie & 291,900 & 482 & 339 & 861.1 \\
Metro $^{3}$ & 788,200 & 435 & 333 & $2,367.0$ \\
Total & $1,585,900$ & 1,853 & 1,481 & $1,070.8$ \\
\hline
\end{tabular}

${ }^{1}$ Estimates from Minnesota State Demographer's office.

${ }^{2}$ Actual number of calls completed.

${ }^{3}$ Metro district includes the following counties--Anoka, Dakota, Hennepin, Ramsey, and Washington. 
Hackett, Ronald L.; Dahlman, Richard A.; Smith, W. Brad.

1991. Residential fuelwood production and sources from

roundwood in Minnesota, 1988. Resour. Bull. NC-133. St. Paul, MN: U.S. Department of Agriculture, Forest Service, North Central Forest Experiment Station. 14 p.

Discusses and analyzes the 1988 Minnesota fuelwood production from roundwood. Analyzes production by geographic area, type of producer, species, landowner class, type of land, and tree source.

KEY WORDS: Growing stock, households, commercial producer, private land. 
Our job at the North Central Forest Experiment Station is discovering and creating new knowledge and technology in the field of natural resources and conveying this information to the people who can use it. As a new generation of forests emerges in our region, managers are confronted with two unique challenges: (1) Dealing with the great diversity in composition, quality, and ownership of the forests, and (2) Reconciling the conflicting demands of the people who use them. Helping the forest manager meet these challenges while protecting the environment is what research at North Central is all about. 